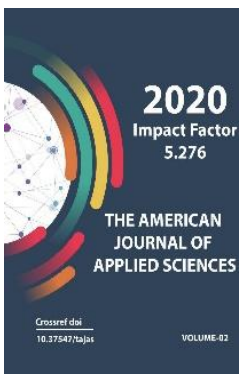

Journal Website: http://usajournalshub.c om/index,php/tajas

Copyright: Original content from this work may be used under the terms of the creative commons attributes 4.0 licence.

\section{Oakh Landscapes And Their Creator Factors Study}

Boymirzaev K.M.

Namangan State University, Uzbekistan

Mirzahmedov I.K.

Namangan State University, Uzbekistan

\title{
ABSTRACT
}

The article describes the study of oasis landscapes by researchers and the factors that create oases, as well as the role of distributed agro-irrigation deposits in the river basins of the Fergana Valley.

\section{KEYWORDS}

Oasis, river spread, valley, agroirrigation deposits, arid, geosystem, landscape - ecological conditions, landscape type, morphological unit, desert, anthropogenic, adyr.

\section{INTRODUCTION}

The Fergana Valley is richer in inland water resources than other regions of Central Asia and Uzbekistan. That is why the valley has been one of the main centers of subsistence farming since ancient times. Adequate inland water resources make it possible to transform the foothill proluvial plains of the Fergana
Valley, conical distributions, steep and steep terraces, hilly and trans-hill plains, Central Fergana deserts, and even hills into irrigated oasis landscapes. While inland waters are an integral, most important component of geocomplexes, they are actively involved in the formation and development of natural 
and anthropogenic landscapes. The existence of oasis landscapes and their functional status are also inextricably linked with inland water sources.

In the spread of hundreds of small rivers and streams in the Fergana Valley, irrigated agriculture has been developed since ancient times, and the landscape complexes of the oasis formed here date back thousands of years. In this study, such spreads, the most fertile landscapes of the Fergana Valley, studied as a result of our personal research, the landscape of the oasis was formed as a result of changes in the landscape complexes of densely populated, densely transformed natural landscapes of rivers and streams. It is said that it came and formed. [5]

Oasis landscapes, which are widespread in arid climates and have a history of formation of several thousand years in time and space, have a special place in the geosystems of Central Asia. Despite the fact that oasis landscape complexes are widespread in Uzbekistan, especially in the Fergana Valley, geographers began to pay much attention to their study, application and mapping as a separate independent natural complex.

Therefore, the study of anthropogenic landscapes and oasis landscapes that are part of them, the separation, delimitation, classification and morphological units of mapping at different scales for different sectors of the economy, the development of methods for forecasting environmental pollution and scientific substantiation. occupies a special place. There is a tendency for agro-irrigation deposits to thicken from year to year in the irrigated agro-landscapes of the valley. It is important to analyze the geochemical composition of such deposits, their richness in organic matter, to develop ways to use them effectively.

\section{MATERIALS AND METHODS}

When describing the nature of some oases in the territory of Uzbekistan, some information can be found in scientific works published in the late XIX century. An example of this is MN Bogdanov's pamphlet "Essays on the nature of the Khiva oasis and the Kyzylkum desert" ("Essays on the nature of the Khivinsk oasis and the desert Kizilkum"), published in 1882. Some ideas about the landscapes of the Central Asian oasis are contained in the scientific article of Yu.G. Saushkin "Cultural Landscape" (1946), in which he noted the emergence of new landscape complexes under the influence of human activities.

F.N.Milkov $(1967,1973,1991)$ is based on manmade landscaping with emphasis on issues related to the study of the oasis landscape. Anthropogenic landscapes, including oasis landscapes, have their own genetic makeup in geosystems, just as the author's natural nature complexes have formed genetic sequences according to their origin. It therefore emphasizes the important scientific and practical significance of their study, research, and mapping.

A.V.Solopov (1971) oasis landscapes and desert land, is located close to the existing relationship between the learner. According to him, due to wind, groundwater and surface currents, there is an interaction between the oasis and the desert geocomplexes. As a result, the exchange of heat, moisture and mineral salts between geosystems is activated. Consequently, due to the interdependence of oasis and desert nature complexes, a single or a whole thermohydrodynamic system is formed.

Comprehensive study of the landscapes of the Central Asian oasis, their morphological composition, separation, delimitation, 
classification, mapping were carried out by AA Abdulkasimov (1977, 1989). The author described the landscapes of the oasis, taking into account the cases of zonal and vertical differentiation. Depending on the type of relief formed by the oasis landscapes, he divided them into several types: oases in the foothills, oases in the intermountain basins, oases in the river valleys, oases in the ancient and modern deltas, oases in the sandy deserts and others. In addition, AA Abdulkasimov (1989) compiled a small-scale map of the landscapes of the Central Asian oasis, largescale landscape typological maps of the Andijan, Fergana, Kokand, Samarkand, Kattakurgan and Denau oases. also identified their main centers of formation.

Researchers of the nature of Uzbekistan are engaged not only in studying the landscapes of the oasis, but also in the formation of agroirrigation deposits in the oases for thousands of years, their properties, role in the formation of landscape complexes, their diversity, as well as also studied its role in increasing productivity.

There is a lot of arable land in Central Asia, which has been irrigated continuously for thousands of years. Irrigated agriculture has changed the natural state of soils for many years. This is because in irrigated agriculture, the temperature of the air adjacent to the soil decreases, the microclimate changes, relative humidity increases, soil moisture regime, microflora composition, humus content, granulometric composition and physical properties change. All of these factors, as well as the combined effect of measures such as plowing and fertilization, have led to the emergence of specific types of soil at different thicknesses [6].

The longer the duration of human economic activity in the soil, the greater the thickness of the agroirrigation deposits. As a result of subsistence farming in Central Asia, it was found that the average annual accumulation of agroirrigation deposits with a thickness of 0.5-1.0 mm (Orlov, 1934). This means that one meter thick agroirrigation deposits are formed in soils that have been cultivated for thousands of years [4].

This type of soil is especially common in the ancient agricultural oases of Central Asia. Another peculiarity of the genesis of such soils is that the process of soil formation is constantly updated due to the fact that a large number of agroirrigation deposits are brought each year. According to M.A. Orlov (1937), in the conditions of the Zarafshan valley, the thickness of the layer of deposits formed due to irrigation of fields can reach 2 $\mathrm{mm}$ per year. As mentioned above, in the oases that have been irrigated for a long time, for example, in the Zarafshan oasis, 3 meters, and in the Messerian oasis in the south-west of Turkmenistan, about 4 meters of agroirrigation deposits have been formed. This type of naturally distributed soils can be found in many places in the Zarafshan and Fergana valleys.

Soils with agro-irrigation deposits are also found in Tashkent, Surkhandarya, Dushanbe, Kulob and other regions, but the thickness of agro-irrigation deposits in these regions does not exceed $50-100 \mathrm{~cm}$. The territory of the above oasis and provinces are connected to a single irrigation source, and differ from each other in terms of color, turbidity, mineralogical and chemical composition of agroirrigation deposits. Accordingly, typical gray soils irrigated have different mechanical composition.

Examination of the mineralogical composition of agro-irrigation deposits has shown that these deposits are composed of a wide variety 
of minerals. They contain more quartz in general, more mica, and less feldspar than typical lyoss and proluvial fine-grained deposits. These studies make it clear and sufficiently clear that the mineralogical structure of agroirrigation deposits is regional in nature [1].

As a result of leveling the surface and fertilizing the soil, the mechanical structure of the soil changes dramatically. Among them, sandy heavy soils are more common, medium sandy soils and loamy soils are less common. Another feature of the soil being tested is the fractional content of the fine particles. It is sparse in lyossimon sandy soils with low dust content, high physical soils and turbid soils [10].

In soils irrigated for a long time, fine fractions, especially turbid ones, increase significantly. The occurrence of such an event indicates that the degradation process is progressing very slowly. In addition to the erosion of lands that have been irrigated for a long time due to the effects of water, some features of meadow soils also appear in these soils. These features are mainly due to the fact that in the humus horizon, due to the processes such as the accumulation and recovery of organic matter, the horizon becomes blue. Another difference between the old irrigated gray soils and the newly irrigated soils is that their humus layer is much thicker.

In general, the study of agroirrigation deposits reveals that this situation is different everywhere. soils with thick agroirrigation deposits indicate the existence of ancient irrigated agriculture in the Tajan and Murgab river basins, in the Khorezm and Zarafshan basins and in the Khorezm plain. In these places, the thickness of the agro-irrigation layer created by human activities reaches 2-3 meters.
Studies on the geographical, soil-geographical, landscape-ecological features of the oases formed in the Fergana Valley and their agroirrigation landscapes AA Abdulkasimov (1965, 1982, 1995, 2012), A. Maksudov (1974, 1993), Yu. Sultanov (1965, 2005), I. Abdug'aniev (1970, 2006), H.Muradov (1991, 1997), B.A.Kamalov (2006, 2012, 2018, 2019), V. Isakov (1990, 2009), G. Yuldashev (1993, 2012), K.M. Boymirzaev (1995, 2003, 2012, 2015, 2019) and others, and landscape-ecological research continues. As a result, the peculiarities of the landscapes of the oasis formed in the valley are revealed, the changes in the components of the landscape as a result of large-scale irrigation farming and the natural processes occurring in them are revealed.

Oasis landscapes are a zonal type of anthropogenic complexes, which differ from the environment not only by their natural conditions, but also by the complexity of their morphological structure. Consequently, oasis landscapes are a zonal view of anthropogenic geosystems created by human activities, irrigated and spring farming is widespread, covered by agrocenoses and characterized by constant human management [3]. It is expedient to study the landscape-ecological problems in the oases of the Fergana Valley, to analyze them comprehensively, to identify the causes of changes in the size of the oases, to identify problems of effective irrigation in these areas and to develop recommendations for effective irrigation. In particular, the analysis of factors forming oases and their natural geographical features, the role of climate and hydrogeological conditions in their formation and development, the study and development of solutions to problems of effective irrigation in oases, forecasting environmental changes under anthropogenic factors, geographical features of oases and highlighting its practical significance, such as 
optimizing the unfavorable environmental conditions in the oases of the Fergana Valley.

The plains occupying the territory of the Fergana Valley - river slopes, overland terraces, plains between the adyroldy and adyr, all the spreads of rivers and streams, a large part of the hilly region have been developed and for many years have been cultivated and irrigated. As a result, natural landscapes have been replaced by anthropogenic oasis landscapes.

For many years, there have been erroneous conclusions that the thickness of agroirrigation deposits in the Fergana Valley does not exceed 1.5 meters, which suggests that the irrigation history in the Fergana Valley is short or there are no conditions for accumulation of agro-irrigation layers.

Scientists conducting research in the Fergana Valley note that in the recent past, the valley area was wetter than it is now, and forest vegetation grew around the cities of Chust and Namangan. The Boburnoma (1993) states that the currently cultivated areas on the left bank of the Syrdarya (Namangan region, Mingbulak district) were covered with tugai and forests during the Babur period, and wild animals were hunted. According to climatologists (Skvortsov, 1927, Sapojnikova, 1951, Chelpanova, 1963, etc.), the climate of the Fergana Valley in the past was cool, and the average annual temperature was 3.5-4.0 degrees lower than today.

Peat deposits have been found in the foothills, which are now occupied by cotton, vineyards and horticulture, among which the remains of coniferous plants have been found. Remains of coniferous plants, we think, may have been caused by a flood. Currently, coniferous trees grow only in mountains with an absolute height of 1,200 meters and above. There is written information about the destruction of ancient springs, irrigation facilities and fortresses in the Fergana Valley due to wars between different tribes. The materials studied suggest that the valley climate has been temperate in the past and has gradually become drier. Some of the agro-irrigation deposits in the Fergana Valley were formed in humid climates. Also, the thickness of the vegetation cover caused a large accumulation of organic residues. The onset of a dry climate has led to a decrease in humidity, the formation of mobile sands and strong winds. As a result, the top layer of soil, rich in organic matter, was left under mobile sands and dusty rocks. sand and sand granulometric rocks began to spread [5].

The thickness of agroirrigation beds, as noted above, depends on the history of farming, the level of turbidity of irrigated water, the hypsometric (slope) condition of the soil, and the fertilization and irrigation techniques. The longer the history of subsistence farming, the thicker the agroirrigation deposits. BV Andrianov (1955, 1967, 1970), NI Bazilevich and LE Rozin (1967) recommend the study of the history of irrigation in the Fergana Valley in a number of stages:

1. The period from the Lower Neolithic to the Bronze Age. At this stage, port irrigation developed and people used the waters of the river. SokhMesolithic, Ashkartepa, Chodakbronze, Kosontepa Sh-I centuries BC, Eylaton I century BC, Dalvarzintepabronze and other agricultural centers with advanced irrigation were found.

2. 2. I-IV centuries AD. During this period, the construction of waterworks began, water was pumped out using dams and sepoys. Munchoktepa (Pop, I century), Kosonsoytepa (IU-I 
centuries BC), Eilaton (I century), Marhamat (I century BC and I century AD), Akhsikent (I-XI century), Oktepa ( Cultural centers such as Western Margilan, U-US centuries) were found.

Agro-irrigation deposits are important not only for the improvement of soil composition, but also for the study of the history of agriculture, the transformation of natural landscapes and the emergence of cultural landscapes in their place. Although the first ideas about this were put forward by M.A. Orlov (1934), M.A. Pankov (1957), S.A. Shuvalov (1967) and other soil scientists, they have not been sufficiently studied. Opinions on agro-irrigation deposits BV Gorbunov (1957), NV Kimberg (1964), NG Minashina (1974), SN Rizhkov (1967), A. Maksudov (1989, 1990, 1995) and KM Boymirzaev (1995, 2001, 2007, 2019). The separation of oasis soils as a separate soil type has also been studied in depth and introduced into science. In addition, materials on the history of agriculture have been enriched with accurate information on the emergence of new soil types, the changing and cultivating nature of natural flora and fauna. Research in this area has been conducted not only in the Fergana Valley, but also in many oases of Central Asia, such as Zarafshan, Tajan-Murgab, and in a number of oases in the Caucasus, such as the Kura-Araks Plain.

\section{RESULTS AND DISCUSSIONS}

Given the complexity of agro-irrigation deposits in the Fergana Valley, the following new gradations (A. Maksudov, 1995) were used instead of the previously adopted thickness indicators and:

1. Agroirrigation beds with very thin (30 $\mathrm{cm}$ ) thickness of irrigated soils;
2. Thin agroirrigation beds (thickness 30$50 \mathrm{~cm})$;

3. Medium-thickness (50-100 cm) agroirrigation deposits;

4. Thick (100-200 cm) agroirrigation deposits;

5. Irrigated cultivated soils with very thick (more than $200 \mathrm{~cm}$ thick) agroirrigation deposits were also found to be common in the Fergana valley.

Landscape typological mapping of oases shows that the genetic type of relief can serve as the main criterion in the separation of oasis types, and in the separation of their internal morphological structure differences in microleaf forms, soil mechanical composition and agrochemistry, groundwater level, thickness of agroirrigation deposits, nature of parent rocks. should be based.

The thickness of agro-irrigation deposits in the direction from the upper to the lower reaches of small rivers differs from the thickness of agro-irrigation deposits of large river basins and has its own regularity. The law is that if the agroirrigation deposits in the upper reaches of large river basins are very thin and sparse, in the upper reaches of small river basins these deposits are thick and very thick. This is due to the fact that large rivers are wet and flow very fast at the exit from the hills, forming deposits of coarse granulometric rocks. Small riverbeds, on the other hand, left soft gravel deposits along with gravel at the exit from the hill zone due to low water content.

The thickening of agroirrigation deposits in the middle parts of large river basins is a more natural geographical location, a combination of relief for water use and water flow. When we study the Sokh spread, one of the largest distributions in the Fergana Valley, we see that 
the general slope of the distribution varies from south to north, ie from the hills to the Syrdarya valley. For example, at the exit of the foothills of the Sokh River, the surface of the floodplain lies at an altitude of $700 \mathrm{~m}$ above sea level, and at the most extreme, near the terrace of the Syrdarya, it drops to $300 \mathrm{~m}$. Both the mechanical composition of the alluvial and prolluvial deposits, which form the spread along this slope, and the thickness of the agroirrigation deposits change (Fig. 1). The water regime of the Sokh River has been strongly altered over the centuries under the influence of human economic activity. The river water is distributed in hundreds of canals and ditches at the confluences, forming a separate Sokh irrigation system. As a result, agricultural landscape complexes, seliteb landscape complexes, irrigation (water economy) landscape complexes, as well as degraded geocomplexes were formed under the influence of human activities in a large part of the distribution [2]. As a result, the landscape complexes of the Kokand oasis, one of the largest oases in the Fergana Valley, were formed in the Sokh extension. The oasis is located in the Sokh conical distribution, starting from the adyroldy plains at the foot of the Alay ridge and flowing inland into the Central Fergana Desert. The Kokand oasis is a "classic" oasis in the Fergana Valley, one of the most strongly developed and modified areas under the influence of human activities. Several types of erosion occurring in the agricultural areas of the Kokand oasis are unfavorable environmental problems. Measures to prevent such processes are being carried out slowly, or the area of pre-existing trees and shrubs is declining from year to year, and in some places is disappearing completely [9].

\section{(Table 1).}

Population growth rate of districts located in Kokand oasis (1989-2019)

\begin{tabular}{|c|c|c|c|c|c|}
\hline \multirow{2}{*}{$\begin{array}{c}\text { Districts } \\
\text { name }\end{array}$} & \multirow{2}{*}{$\begin{array}{c}\text { Year of } \\
\text { establishment }\end{array}$} & \multicolumn{4}{|c|}{ Population, thousand people } \\
\cline { 3 - 6 } & $\mathbf{1 9 8 9}$ & $\mathbf{2 0 1 0}$ & $\begin{array}{c}\mathbf{2 0 1 6} \\
\text { year }\end{array}$ & $\begin{array}{c}\text { year } \\
\text { year }\end{array}$ \\
\hline Beshariq & 29.09 .1926 & 140.9 & 181.2 & 208.1 & 224.6 \\
\hline Bagdad & 31.12 .1964 & 108.0 & 174.8 & 193.3 & 210.4 \\
\hline Buvayda & 26.12 .1973 & 111.2 & 178.9 & 206.4 & 222.2 \\
\hline Dangara & 07.12 .1970 & 87.3 & 144.1 & 158.0 & 170.1 \\
\hline Uchkuprik & 29.09 .1926 & 113.9 & 183.3 & 206.6 & 224.4 \\
\hline Furqat & 09.04 .1992 & - & 97.1 & 107.6 & 115.8 \\
\hline Uzbekistan & 17.04 .1963 & 142.6 & 194.5 & 217.3 & 234.3 \\
\hline
\end{tabular}

The table was compiled by the authors using data from the Fergana Regional Statistics Office.

It is known that the Fergana Valley is one of the most densely populated regions in the country. As can be seen from the table, the
Kokand oasis differs from other oases of the valley by its area with the fastest population 
growth. The development of agriculture on irrigated lands, pastures and meadows, as well as the use of arable lands for various purposes, changes the lithologicalgeomorphological, mechanical composition of soil, water and air regime, physical, agrochemical and chemical-biological properties [8].

The results of research in the Kokand oasis showed that the development of lands without taking into account the specific features of arid areas has led to the formation of processes such as leaching of soil in large areas, various manifestations of erosion, rising groundwater levels, salinization and salinization. Therefore, in the development of arid lands, land and water use should be based on the latest achievements of science and technology, as well as the positive impact of human economic activity.

In the middle reaches of small riverbeds, however, irrigation is different everywhere due to water scarcity, and agroirrigation deposits are sometimes thick, in some plots of medium thickness, and in some places very thick and buried. Buried agroirrigation bed soils have also appeared in some depressions in the middle reaches of large depressions and in ancient valleys. All these processes have had a different impact on the productivity of agro-landscapes, which can be divided into the following productivity indicators (K. Boymirzaev, 2019):

1. Oasis landscape complexes with very thin $(0-30 \mathrm{~cm})$ thickness of agroirrigation deposits, where the productivity of agro-landscapes is unsatisfactory;
2. Oasis landscape complexes with fine agro-irrigation deposits with satisfactory productivity of agrolandscapes, thickness (up to 30-50 $\mathrm{cm}$ );

3. Oasis landscape complexes with average productivity of agrolandscapes, agro-irrigation deposits with average thickness $(50-100 \mathrm{~cm})$;

4. Oasis landscape complexes with good productivity of agro-landscapes, agroirrigation deposits with thickness of 100-200 cm;

5. Irrigated cultivated oasis landscape complexes with excellent productivity of agro-landscapes, very thick (more than $200 \mathrm{~cm}$ in thickness) agroirrigation and buried deposits under them were also found in the Fergana Valley.

The Chartaksay spread, which is one of the small river spreads, is located in the northern part of the Fergana Valley, between the Naryn River and Namangansay. After leaving the Namangan hill ridge, Chartaksay forms its small conical distribution in the pre-hill plain. The southern boundary of the spread is connected with the terraces of the Syrdarya and Naryn rivers.

The relief of the Chartaksay spread is a conical sloping plain, descending from north to south, from the hills to the valley of the Naryn River. In the Chartaksay spread, there are no pebbles typical of the upper part of the Sokh spread, gravels occupying large areas, desert landscapes composed of sparse xerophytic plants, formed in arid climates. 
The thickness of the agroirrigation deposits on the way from the upper to the lower part of the Chartaksay spread differs from the thickness of the agroirrigation deposits of the Sokh spread and has its own regularity (Fig. 3). The regularity is that if the agroirrigation deposits in the upper parts of the Sokh spread are very thin and sparse, in the upper part of the Chartaksay spread these deposits are thick and very thick. This is due to the fact that the Sokh River is wet and flows very fast at the exit from the hills, forming deposits of coarse granulometric rocks. Due to the lack of water, Chartaksay left gravel along with gravel when leaving the hills. The water of the Sokh River was also initially difficult to use for agriculture in the upper reaches of the spread. Chartaksay water was used from the upper part of the spread [5].

The thickening of agroirrigation deposits in the middle parts of the Sokh spread is a more natural geographical location, a combination of relief for water use and water flow. In the middle part of the Chartaksay spread, however, irrigation is different everywhere due to water scarcity, with agro-irrigation deposits sometimes thick, in some areas moderately thick, and in some places very thick and buried. Buried agroirrigation sedimentary soils also appeared in some depressions and ancient valleys in the middle parts of the Sokh spread.

The margins of both spreads are occupied by thin agroirrigation deposits, while in the Sokh spread they are much and strongly saline, while in the Chartaksay spread they are not saline due to the alluvial regime.

Although the soil and ecological condition of the Chartaksay spread is not as complex as that of the Sokh spread, it has its own differences. The agroirrigation deposits in the Chartaksay spread are much thicker than in the Sokh spread. Very thick agroirrigation deposits were formed in the upper parts of the Chartaksay spread. In the middle part of the spread, thick and buried agroirrigation bed soils are common. The soils of a large part of the Chartaksay spread are highly cultivated. The process of salinization of soils, which is typical for the spread of soybeans, and the formation of salts do not occur in the soils of the Chartaksay spread.

\section{CONCLUSION}

Emerging and emerging landscape of the Fergana Valley oasis - taking into account the morphological structure and local natural conditions of geocomplexes, optimization of ecological conditions and high efficiency in all sectors of our economy, the introduction of crop rotation, the use of organic and mineral fertilizers, reclamation - it is necessary to implement measures in a timely manner, to use labor resources in accordance with the purpose. It is natural that the integrated implementation of the developed set of measures will allow to stabilize the ecological balance in the landscapes of the oasis [6].

Also, natural and anthropogenic factors in the formation, development and formation of the landscapes of the Fergana Valley oasis are much more complex than in the small spreads. For example, anthropogenic complexes occupy all parts of the small distribution. Large areas in the upper and middle parts of large spreads are less exposed to human influence. In large spreads, the curved lines, reminiscent of the thickness of agroirrigation deposits, are complex and curvilinear. All this shows that the anthropogenic factor is closely related to the natural factor. Differences in the natural components of the distribution of large and small rivers in the Fergana Valley indicate that the landscapes in these oases are evolving and changing in different conditions. 


\section{REFERENCES}

1. Abbasov S.B. Ecological aspects of sustainable development of desert areas // Sustainability in the economy and environmental protection. - Tashkent: TSU, 2006, pages 85 - 86 .

2. Abdulqosimov A, Kuziboeva O. Sokh distribution landscapes microzone planting and reclamation assessment. Samarkand .: SamSU, 2009. - 134 pages.

3. Abdulkosimov A.A., Abdulkosimov A., Abdulkosimov I. Anthropogenic landscape SredneyAzii. T .: "Economy Finance". 2016. - 262 p.

4. Boymirzaev K.M. Landscapes of the oasis: origin, formation and development // Information of the Geographical Society of Uzbekistan. 24 - vol. T .: 2004, pp. 45 - 49.

5. Boymirzaev K.M. Use of landscapes of the Fergana Valley oasis and protection Toshkent; Science, 2007, p.130.

6. Boymirzaev K.M., Mirzahmedov I.K. Groundwater of the oases of the Fergana Valley and their hydrogeological features // Information of the Geographical Society of Uzbekistan. 46 - vol. - Tashkent, 2019. Pages 44 - 47.

7. Maksudov A. Change of soil - ecological conditions Fergana valley under anthropogenic weather. Tashkent; Fan, 1990. $92 \mathrm{p}$.

8. Mirzahmedov I.K. Features of the formation and development of the soil of the oasis of the Fergana Valley // Science and Earth. №1. Scientific journal. Xujand, 2020. - p. 32 - 36.

9. Mirzajonov K., Nazarov M., et al. Soil protection. - T: Science and Technology Publishing House. 2004.

10. Morgan R. Soil erosion and conservation. A: 2005.p 316.
11. Muhamadjonovna, S. D. (2020). The key concepts of forming sociolinguistic competence of future English language specialists. Asian Journal of Multidimensional Research (AJMR), 9(5), 118-121.

12. Muhamadjonovna, S. D. (2020). The development of sociolinguistic competence of future English language teachers through computer technologies. 